\title{
Hubungan oral hygiene dengan Coated Tongue pada ibu hamil
}

\author{
Nabilla Rifda Arintya ${ }^{1 *}$, Wahyu Hidayat ${ }^{1}$, Tenny Setiani Dewi ${ }^{1}$ \\ ${ }^{1}$ Departemen Ilmu Penyakit Mulut, Fakultas Kedokteran Gigi Universitas Padjadjaran, Indonesia \\ *Korespondensi: nabilla14006@mail.unpad.ac.id
}

\begin{abstract}
ABSTRAK
Pendahuluan: Kehamilan adalah suatu kondisi yang dapat mempengaruhi perubahan fisiologis, perubahan pola makan, dan perubahan psikologis. Hal ini secara tidak langsung dapat mempengaruhi status kebersihan mulut dan selaput lidah. Sebagian besar wanita hamil ditemukan menderita beberapa penyakit mulut yang diketahui terkait dengan kehamilan. Tujuan penelitian untuk mengetahui hubungan antara oral hygiene dengan coated tongue pada ibu hamil di Puskesmas Garuda Bandung. Metode: Jenis penelitian analitik korelatif dengan pendekatan cross-sectional. Sampel yang memenuhi kriteria adalah sebanyak 69 orang yang diperoleh dengan teknik purposive sampling. Data diperoleh dengan menghitung Oral Hygiene Index Simplified dan Coated Tongue Index, kemudian data dianalisis dengan menggunakan uji korelasi Spearman menggunakan aplikasi MegaStat. Hasil: Hubungan antara oral hygiene dan coated tongue pada kelompok ibu hamil di Puskesmas Garuda Bandung, mempunyai nilai korelasinya $\left(\mathrm{r}_{\mathrm{s}}\right)$ sebesar 0,259 menunjukkan Nilai signifikan secara statistik dengan p-value sebesar 0,00158567 $(\mathrm{p}<0,005)$. Simpulan: Terdapat hubungan antara oral hygiene dan coated tongue pada kelompok ibu hamil, yang berarti ketika kebersihan rongga mulut buruk, area selaput putih (coated tongue) pada dorsal lidah semakin besar.
\end{abstract}

Kata kunci: Oral hygiene, coted tongue, kehamilan

\section{Relationship between oral hygiene and Coated Tongue in pregnant women}

\section{ABSTRACT}

Introduction: Pregnancy is a condition that affects physical, dietary habit, and physicological changes. These changes affect oral hygiene and coated tongue indirectly. Most pregnant women are found to suffer from some oral diseases that associated with pregnancy. The aim of this study was to determine the relationship of oral hygiene with coated tongue among pregnant women in Puskesmas Garuda Bandung. Methods: This study used correlative analytical with cross sectional approach method. The samples were 69 pregnant women that were obtained by purposive sampling technique. The data was obtained by examining the Oral Hygiene Index Simplified and coated tongue index. The data were analyzed using Spearman Correlation and proceeded by MegaStat application. Result: There was a relationship between oral hygiene status and coated tongue among pregnant women in Puskesmas Garuda Bandung. The correlation value $\left(r_{s}\right)$ was 0,259 which is statistically significant ( $p$-value $\left.<0,05\right)$. Conclusion: There was a relationship between oral hygiene status and coated tongue among pregnant women in Puskesmas Garuda Bandung, which means when oral hygiene status was bad, the area of the white membrane on the dorsal of the tongue (coated tongue) was wider and vice versa.

Keywords: Oral hygiene, coated tongue, pregnancy 


\section{PENDAHULUAN}

Saat kehamilan terjadi perubahan fisiologis pada wanita hamil yang mempengaruhi biokimia normal. Perubahan hormonal yang terjadi pada masa kehamilan dapat berdampak pada beberapa bagian tubuh termasuk rongga mulut. ${ }^{1}$ Sebagian besar wanita hamil ditemukan menderita beberapa penyakit mulut yang diketahui berhubungan dengan kehamilan. Perubahan hormonal tidak hanya mempengaruhi suplai darah ke jaringan gusi, tetapi juga respon tubuh terhadap toksin yang menyebabkan pembentukan plak. Perubahan tingkat hormon steroid menyebabkan penurunan kecepatan aliran saliva, perubahan $\mathrm{pH}$ saliva, dan perubahan komposisi biokemikal saliva sehingga mempengaruhi self cleansing rongga mulut. ${ }^{2-4}$

Wanita hamil juga mengalami perubahan pola diet. Konsumsi daging merah, minyak lemak, minyak salad, puding, krim, susu, dan keju meningkat pada wanita hamil pada masa kehamilan akhir. ${ }^{5}$ Makanan lunak atau soft food dapat meningkatkan pembentukan plak. Meski hanya sedikit, jumlah coated tongue berhubungan secara positif dengan asupan soft food. ${ }^{6,7}$

Wanita hamil sering merasa khawatir terhadap kesehatan dirinya, kesehatan bayinya, dan rasa sakit yang nantinya akan dirasakan pada saat persalinan. Kekhawatiran atau rasa cemas ini adalah salah satu faktor penyebab wanita hamil mengalami stres. Stres psikososial dapat menyebabkan kebersihan mulut tidak terjaga dan peningkatan akumulasi plak. ${ }^{8}$

Kebersihan mulut adalah faktor terbesar yang menyebabkan coated tongue. ${ }^{9}$ Coated tongue memiliki peran dalam infeksi rongga mulut, salah satunya coated tongue dapat menyebabkan infeksi Candida sp. Coated tongue tersusun oleh bakteri, sejumlah besar epitel terdeskuamasi yang dilepaskan dari mukosa oral, leukosit dari poket periodontal, metabolit darah, dan sisa makanan yang dapat menyebabkan perkembangan infeksi dan halitosis. ${ }^{10}$ Infeksi tersebut dapat menyebabkan ketidaknyamanan, perubahan pada sensasi pengecapan, dan disfagia yang menyebabkan kurangnya asupan nutrisi. ${ }^{11}$

Puskesmas Garuda Bandung adalah salah satu Puskesmas di Kota Bandung yang memiliki program pelayanan untuk ibu hamil. Program tersebut adalah PONED (Pelayanan Obstetri Neonatus Essensial Dasar). Program ini dilakukan oleh Puskesmas yang memiliki fasilitas atau kemampuan dalam penanganan kegawatdaruratan obsetri dan neonatal dasar. Oleh karena itu jumlah kunjungan pasien ibu hamil cukup banyak di Puskesmas Garuda Bandung. Selain itu belum pernah dilakukan penelitian mengenai hubungan oral hygiene dengan coated tongue pada pasien-pasien ibu hamil tersebut, berdasarkan uraian di atas, peneliti tertarik untuk mengetahui hubungan antara oral hygiene dengan coated tongue pada ibu hamil di Puskesmas Garuda Bandung. Tujuan dari penelitian ini adalah untuk mengetahui hubungan antara oral hygiene dengan coated tongue pada ibu hamil di Puskesmas Garuda Bandung.

\section{METODE}

Jenis penelitian yang digunakan adalah penelitian analitik korelatif dengan pendekatan cross sectional. Penelitian ini dilakukan dengan cara pengamatan langsung subjek untuk mempelajari dinamika korelasi antara faktor risiko dengan efek, dengan cara pengumpulan data sekaligus pada saat itu. Populasi dalam penelitian ini adalah ibu hamil yang tercatat melakukan kunjungan di Puskesmas Garuda Bandung. Sampel pada penelitian ini diambil dengan teknik purposive sampling.

Pengambilan sampel didasarkan pada pertimbangan tertentu yang dibuat oleh peneliti sendiri, berdasarkan ciri atau sifat-sifat populasi yang sudah diketahui sebelumnya. Kriteria inklusi adalah semua ibu hamil yang tidak memiliki penyakit sistemik dan tidak dalam pengobatan. Kriteria ekslusi adalah ibu hamil yg menderita diabetes, tbc, ibu hamil yg mengkonsumsi obat2 anti biotik spektrum luas, ibu hamil yang mengalami terapi obat-obatan untuk kelainan saraf. Jumlah sampel minimal ditentukan dengan menggunakan rumus besar sampel analitik korelatif. Jumlah sampel minimal berdasarkan rumus tersebut adalah 54 orang.

Variabel penelitian adalah oral hygiene simplified dan Coated Tongue. Status oral hygiene dicatat dengan skor baik, sedang dan buruk, dimana 0,0 -1,2 = skor baik, 1,3 -3,0 = skor sedang dan 3,1 $6,0=$ skor buruk; sedangkan skor coated tongue $0=$ tidak ada coated tongue, $1=$ coated tongue $1 / 3$ dorsal lidah, $2=$ coated tongue $1 / 2$ dorsal lidah, $3=$ coated tongue lebih dari $2 / 3$ dorsal lidah.

Instrumen yang digunakan pada penelitian ini diantaranya baki, alat dasar yang terdiri dari kaca mulut, sonde, dan pinset gelas kumur, senter 
petridish, alat tulis informed consent, formulir data responden, formulir hasil pemeriksaan OHI-S dan pemeriksaan selaput lidah, dan kamera untuk dokumentasi. Bahan-bahan yang digunakan dalam prosedur ini diantaranya alkohol 70\%, savlon, kasa steril, tissue, tampon, air, sabun cair antiseptik. Penelitian dilakukan pada bulan Desember 2017 di UPT Puskesmas Garuda Bandung yang beralamat di
Jalan Dadali Nomor 81 Kota Bandung, Jawa Barat. Data dianalisis dengan menggunakan tabel dan grafik. Analisis statistik dilakukan menggunakan uji korelasi Spearman yang bertujuan untuk mengetahui hubungan antara oral hygiene dengan coated tongue pada ibu hamil di Puskesmas Garuda Bandung. Penelitian ini sudah melalui ethical clearance dengan nomor surat persetujuan etik 0217111192.

\section{HASIL}

Tabel 1. Oral hygiene simplified

\begin{tabular}{|c|c|c|c|c|c|c|c|c|}
\hline \multirow{3}{*}{$\begin{array}{c}\text { Status Oral } \\
\text { Hygiene }\end{array}$} & \multicolumn{6}{|c|}{ Usia Kehamilan } & \multirow{2}{*}{\multicolumn{2}{|c|}{ total }} \\
\hline & \multicolumn{2}{|c|}{ Trimester 1} & \multicolumn{2}{|c|}{ Trimester 2} & \multicolumn{2}{|c|}{ Trimester 3} & & \\
\hline & Jumlah & $(\%)$ & Jumlah & (\%) & Jumlah & $(\%)$ & Jumlah & $(\%)$ \\
\hline Baik & 6 & $8,70 \%$ & 7 & $13,04 \%$ & 13 & $18,84 \%$ & 26 & $37,68 \%$ \\
\hline Sedang & 2 & $2,90 \%$ & 14 & $20,29 \%$ & 22 & $31,88 \%$ & 38 & $55,07 \%$ \\
\hline Buruk & 1 & $1,45 \%$ & 1 & $1,45 \%$ & 3 & $4,35 \%$ & 5 & $7,25 \%$ \\
\hline Total & 9 & $13,04 \%$ & 22 & $34,78 \%$ & 38 & $55,07 \%$ & 69 & $100,00 \%$ \\
\hline
\end{tabular}

Tabel 2. Skor coated tongue berdasarkan indeks ${ }^{6}$

\begin{tabular}{|c|c|c|c|c|c|c|c|c|}
\hline \multirow{3}{*}{ Skor Coated Tongue } & \multicolumn{6}{|c|}{ Usia Kehamilan } & \multirow{2}{*}{\multicolumn{2}{|c|}{ total }} \\
\hline & \multicolumn{2}{|c|}{ Trimester 1} & \multicolumn{2}{|c|}{ Trimester 2} & \multicolumn{2}{|c|}{ Trimester 3} & & \\
\hline & Jumlah & (\%) & Jumlah & (\%) & Jumlah & (\%) & Jumlah & (\%) \\
\hline 0 & 2 & $2,90 \%$ & 6 & $10,14 \%$ & 7 & $10,14 \%$ & 15 & $21,74 \%$ \\
\hline 1 & 1 & $1,45 \%$ & 8 & $10,14 \%$ & 11 & $15,94 \%$ & 20 & $28,99 \%$ \\
\hline 2 & 4 & $5,80 \%$ & 3 & $5,80 \%$ & 10 & $14,49 \%$ & 17 & $24,64 \%$ \\
\hline 3 & 2 & $2,90 \%$ & 5 & $8,70 \%$ & 10 & $14,49 \%$ & 17 & $24,64 \%$ \\
\hline Total & 9 & $13,04 \%$ & 22 & $34,78 \%$ & 38 & $55,07 \%$ & 69 & $100,00 \%$ \\
\hline
\end{tabular}

Tabel 3. Oral hygiene dan coated tongue

\begin{tabular}{|c|c|c|c|c|c|c|c|c|}
\hline \multirow{3}{*}{ Indeks $^{6}$} & \multicolumn{6}{|c|}{ OHI-S } & \multirow{2}{*}{\multicolumn{2}{|c|}{ Total }} \\
\hline & \multicolumn{2}{|c|}{ Baik } & \multicolumn{2}{|c|}{ Sedang } & \multicolumn{2}{|c|}{ Buruk } & & \\
\hline & Jumlah & (\%) & Jumlah & (\%) & Jumlah & (\%) & Jumlah & (\%) \\
\hline 0 & 9 & $13,04 \%$ & 6 & $8,70 \%$ & 0 & $0,00 \%$ & 15 & $21,74 \%$ \\
\hline 1 & 8 & $10,14 \%$ & 12 & $17,39 \%$ & 0 & $0,00 \%$ & 20 & $28,99 \%$ \\
\hline 2 & 3 & $5,80 \%$ & 11 & $15,94 \%$ & 3 & $4,35 \%$ & 17 & $24,64 \%$ \\
\hline 3 & 6 & $8,70 \%$ & 9 & $13,04 \%$ & 2 & $2,90 \%$ & 17 & $24,64 \%$ \\
\hline Total & 26 & $37,68 \%$ & 38 & $55,07 \%$ & 5 & $7,25 \%$ & 69 & $100,00 \%$ \\
\hline
\end{tabular}

Tabel 4. Spearman correlation test

\begin{tabular}{cccccc}
\hline Var & $\mathbf{r}_{\mathbf{s}}$ & $\mathbf{t}_{\text {hit }}$ & p-value & Sifat & Korelasi \\
\hline OHI-S \& CoTo & 0,259 & 2,19 & 0,0158567 & sign & 6,70 \\
\hline
\end{tabular}

Tabel 1 menunjukan bahwa mayoritas ibu hamil di Puskesmas Garuda Bandung memiliki oral hygiene yang baik yaitu sebanyak 58 orang $(37,68 \%)$. Ibu hamil yang memiliki oral hygiene buruk hanya sebanyak lima orang $(7,25 \%)$, yaitu satu orang $(1,45 \%)$ pada usia kehamilan trimester pertama, satu orang $(1,45 \%)$ pada usia kehamilan trimester kedua, dan tiga orang $(4,35 \%)$ pada usia kehamilan trimester ketiga.

Tabel 2 menunjukkan bahwa hanya 15 orang ibu hamil $(21,74 \%)$ yang tidak terdapat coated tongue pada dorsal lidahnya dan 54 orang ibu hamil $(78,26 \%)$ ditemukan terdapat coated tongue pada lidahnya dengan skor yang bervariasi. Sebanyak 20 orang $(28,99 \%)$ ibu hamil ditemukan terdapat coated tongue pada kurang dari $1 / 3$ bagian dorsal 
lidah (skor 1), sebanyak 17 orang (24,64\%) ibu hamil terdapat coated tongue pada lebih dari $1 / 3$ namun kurang dari $2 / 3$ dorsal lidah (skor 2), dan sebanyak 17 orang $(24,64 \%)$ ibu hamil ditemukan terdapat coated tongue pada lebih dari $2 / 3$ bagian dorsal lidahnya (skor 3). Tabel 3 menunjukan gambaran status oral hygiene dan coated tongue.

Tabel 3 menunjukkan bahwa frekuensi tertinggi sebanyak 12 responden (17,39\%) memiliki kebersihan mulut sedang dan terdapat coated tongue pada dorsal lidah lebih dari $1 / 3$, namun kurang dari $2 / 3$ permukaan dorsal lidahnya (skor 2 ). Tidak ada responden yang memiliki oral hygiene yang buruk tanpa coated tongue pada dorsal lidahnya. Sebanyak tiga responden dengan oral hygiene buruk $(4,35 \%)$ ditemukan terdapat coated tongue pada dorsal lidahnya lebih dari $1 / 3$ (skor 2) dan dua responden $(2,90 \%)$ ditemukan terdapat coated tongue pada dorsal lidahnya lebih dari 2/3 (skor 3). Hubungan oral hygiene dengan coated tongue diuji dengan uji korelasi Spearman. Hasil dari uji korelasi Spearman disajikan pada tabel 4 hasil analisis menunjukan nilai korelasi $\left(\mathrm{r}_{\mathrm{s}}\right)$ sebesar 0,259 yang bersifat signifikan secara statistik dengan p-value sebesar 0,00158567 $(\mathrm{p}<0,005)$. Berdasarkan hasil analisis tersebut oral hygiene memiliki hubungan yang signifikan dengan coated tongue dengan persentase keterkaitan sebesar 6,70\%. Secara umum, apabila skor OHI-S meningkat, skor coated tongue juga meningkat pada kelompok ibu hamil yang berjumlah 69 orang di Puskesmas Garuda Bandung dan begitupun sebaliknya.

\section{PEMBAHASAN}

Hasil penelitian yang dilakukan pada 69 ibu hamil di Puskesmas Garuda Bandung menunjukan bahwa sebagian besar ibu hamil memiliki status oral hygiene yang sedang, yaitu lebih dari separuh responden (55,07\%). Responden yang memiliki status oral hygiene buruk hanya sebesar $7,25 \%$ dan responden yang memiliki status oral hygiene baik adalah sebesar 37,68\%. Hal ini menunjukan bahwa ibu hamil di Puskesmas Garuda Bandung yang memiliki status oral hygiene baik dan sedang lebih banyak dibandingkan dengan ibu hamil yang memiliki status oral hygiene buruk. Hal ini sejalan dengan hasil penelitian yang dilakukan oleh Hidayati, dkk. pada kelompok ibu hamil di wilayah kerja Puskesmas Andalas, yaitu sebagian besar ibu hamil mempunyai status kebersihan mulut yang sedang dan hanya sebagian kecil yang memiliki status kebersihan mulut yang buruk. ${ }^{12}$

Tabel 3 menunjukan bahwa jumlah ibu hamil yang terdapat coated tongue pada dorsal lidanya $(78,26 \%)$ lebih banyak daripada ibu hamil yang tidak terdapat coated tongue pada dorsal lidahnya (21,74\%). Hal ini dapat dipengaruhi oleh kebiasaan dan prosedur menyikat lidah pada saat menyikat gigi. Menyikat lidah tidak hanya memperbaiki penampilan klinis, tetapi juga dapat mengurangi populasi bakteri pada dorsal lidah. Oleh karena itu, menyikat lidah dengan cara yang benar dan teratur sebaiknya menjadi bagian dari prosedur oral hygiene pada setiap individu. ${ }^{9}$

Oral hygiene merupakan salah satu faktor yang berkaitan dengan coated tongue. Hasil analisis statistik (Tabel 4) memperlihatkan hubungan oral hygiene dengan coated tongue. Terdapat korelasi positif antara oral hygiene dan coated tongue. Uji korelasi Spearman menunjukan nilai korelasi $\left(\mathrm{r}_{\mathrm{s}}\right)$ sebesar 0,259 . Nilai korelasi ini bersifat signifikan secara statistik dapat dilihat dari p-value sebesar $0,00158567(p<0,005)$. Artinya apabila skor OHI-S meningkat, skor coated tongue juga meningkat dan begitupun sebaliknya. Penelitian yang dilakukan oleh Van Tornout, et al. ${ }^{6}$ yang dilakukan pada tahun 2012 pada pasien halitosis menunjukan faktorfaktor yang berkaitan dengan coated tongue yang diukur berdasarkan indeks. ${ }^{6}$ Hasil penelitian menunjukan nilai korelasi $\left(\mathrm{r}_{\mathrm{s}}\right.$ ) oral hygiene dengan coated tongue yang lebih besar, yaitu sebesar 0,373. Hal ini juga sejalan dengan penelitian yang dilakukan Rahmayanti dimana terdapat korelasi positif antara oral hygiene dengan coated tongue pada remaja usia 12-13 tahun dengan nilai korelasi $\left(r_{s}\right)$ yang lebih kecil, yaitu sebesar $0,186 .{ }^{13}$ Perbedaan tersebut dapat terjadi akibat perbedaan karakteristik sampel serta kriteria inklusi dan ekslusi.

Tingkat hormon gonadotropin (HCG), beta-endorphin, estrogen dan progersteron meningkat selama kehamilan. Peningkatan terbesar adalah pada trimester ketiga kehamilan. Selain perubahan fisiologis, wanita hamil juga mungkin mengalami perubahan psikologis yaitu stres. Sebagai respon dari stress, neuron hipofisiotrofik di nukleus paraventrikular hipotalamus menjadi aktif dan kemudian mensekresikan dua hormon, yaitu corticotropin-releasing hormone (CRH) dan vasopressin arginine (AVP) ke dalam sirkulasi. Kedua hormon tersebut bekerja pada hipofisis anterior 
untuk mempromosikan sekresi adrenocorticotropic hormone (ACTH). ACTH akan bekerja pada korteks adrenal bagian dalam untuk memulai sintesis dan pelepasan hormon glukokortikoid, yaitu hormon kortisol. Stres kronik dapat menyebabkan peningkatan sekresi CRH yang berdampak pada peningkatan sekresi hormon kortisol di kelenjar adrenal. ${ }^{14}$ Peningkatan hormon-hormon tersebut menyebabkan penurunan kecepatan aliran saliva. ${ }^{3}$ Gangguan aliran saliva menyebabkan keratin pada dorsal lidah tidak terangsang untuk mengelupas sehingga terjadi penumpukan selaput pada lidah, penumpukan selaput tersebut menyebabkan terbentuknya plak putih atau berwarna. ${ }^{15}$

Terbentuknya coated tongue juga dapat disebabkan perbedaan bentuk anatomis lidah dan papila pada dorsal lidah pada masing-masing individu. Pada permukaan dorsal lidah terdapat fissure dan area berpapila, yaitu papilla fungiform dan papilla filiform. Hal ini menyebabkan retensi bakteri pada daerah tersebut. ${ }^{9}$

Coated tongue juga dapat disebabkan karena karakteristik makanan yang dikonsumsi. ${ }^{6}$ Wanita hamil mengalami suatu adaptasi fisiologis. Adaptasi fisiologis tersebut berupa perubahan pada sistem hormon dan sistem neuroendrokrin yang mengendalikan nafsu makan dan mengendalikan keseimbangan energi selama kehamilan. ${ }^{16}$ Konsumsi daging merah, minyak lemak, minyak salad, pudding, krim, susu, dan keju meningkat pada wanita hamil pada masa kehamilan akhir. Hal ini bertujuan untuk menyediakan nutrisi bagi janin yang sedang tumbuh dan mempersiapkan proses laktasi setelah kelahiran. ${ }^{5}$ Konsumsi soft food merupakan salah satu faktor yang berkaitan dengan terbentuknya coated tongue. ${ }^{6}$

Penelitian ini menunjukan terdapat hubungan oral hygiene dengan coated tongue yang bersifat signifikan. Selain oral hygiene, terdapat faktor-faktor lain yang berkaitan dengan terbentuknya coated tongue pada wanita hamil. Faktor lain yang mungkin berkaitan dengan coated tongue pada wanita hamil diantaranya adalah tingkat hormon yang mempengaruhi karakteristik saliva, bentuk anatomis lidah, pola makan saat kehamilan, dan karakteristik makanan yang dikonsumsi wanita hamil.

\section{SIMPULAN}

Terdapat hubungan antara oral hygiene dengan coated tongue pada kelompok ibu hamil di
Puskesmas Garuda Bandung yang berarti ketika kebersihan rongga mulut buruk, area selaput putih (coated tongue) pada dorsal lidah semakin luas.

\section{DAFTAR PUSTAKA}

1. Soma-Pillay P, Nelson-Piercy C, Tolppanen H, Mebazaa A. Physiological changes in pregnancy. Cardiovas J Africa 2016;27(2):89-94.

2. Sonia S, Shivhare UD, Sakarkar. Oral infections, a mirror of our overall health condition: An overview. Intern J Pharm Life Scien 2013;4(9).

3. Karnik AA, Pagare S, Krishnamurthy V, Vahanwala $\mathrm{S}$. Determination of salivary flow rate, $\mathrm{pH}$, and dental caries during pregnancy: A study. J Indian Acad Or Med Rad 2015;27(3):372-6. DOI: 10.4103/0972-1363.170454.

4. Mostary Z, Masuma A, Ayasha A, Ranzu A; Akhtar A. Oral hygiene and dental health among pregnant women attending in a selected hospital in Dhaka City. Oral Health Manag 2016;15(6):66.

5. Crozier SR, Robinson SM, Godfrey KM, Cooper C, Inskip HM. Women' s dietary patterns change little from before to during pregnancy. J Nutr. 2009 Oct;139(10):1956-63. DOI: 10.3945/ jn.109.109579. Epub 2009 Aug 26.

6. Tornout MV, Dadamio J, Coucke W, Quirynen M. Tongue coating: Related factors. J Clin Periodon 2012:40(2):180-5. DOI: 10.1111/jcpe.12031

7. Chernoff R. Geriatric nutrition the health professional's handbook. $3^{\text {rd }}$ ed. Burlington MA: Jones \& Bartlett Learning. 2014. h. 190.

8. Deinzer R, Hilpert D, Bach K, Schawacht M, Herforth A. Effects of academic stress on oral hygiene-A potential link between stress and plaque-associated disease. J Clin Periodont 2001;28(5):460-64.

9. Danser MM, Gómez SM, Van der Weijden GA. Tongue coating and tongue brushing: A literature review. 2003;Aug;1(3):151-8.

10. Derceli JdR, Pires JR, Tardivo TA, Massucato EMS, Orrico SRP, Spolidorio DM. Comparative study of the clinical and anti-microbial efficacy of tongue cleaners. Brazilian J Or Scien 2007;6(22):1407

11. Akpan A, Morgan R. Oral candidiasis. Postgraduate Med J 2002;78(922):455-59.

12. Hidayati, Kuswardani, Rahayu G. Pengaruh kebersihan gigi dan mulutdengan status gingivitis pada ibu hamil di wilayah kerja Puskesmas Andalas Kecamatan Padang Timur Kota Padang. 
Maj Kedok Andalas, 2012;36(2):215-23. DOI: 10.22338/mka.v36.i2.p215-224.2012.

13. Rahmayanti, Zenita Aisah. Hubungan Kebersihan Mulut dengan Coated Tongue pada Remaja Usia 12-13 Tahun. Bandung: Skripsi Fakultas Kedokteran Gigi: Universitas Padjadjaran. 2015. h. 38 .

14. Ulrich-Lai YM Herman JP. Neural regulation of endocrine and autonomic stress responses. Nat
Rev Neurosci 2009:10(6):97-409. DOI: 10.1038/ nrn2647.

15. Field, Anne, and Lesley Logman. Tyldesley's Oral Medicine. Oxford: Oxford University Press. 2003. h. 68.

16. Douglas AJ,Johnstone LE, Leng G. Neuroendocrine mechanisms of change in food intake during pregnancy: A potential role for brain oxytocin. Physiology \& Behavior, 2007;91(4):352-65. 